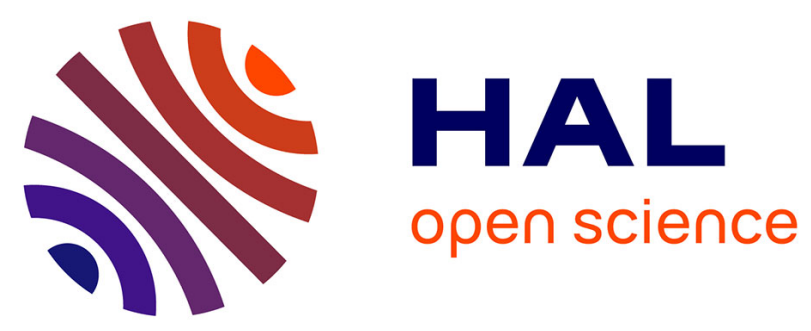

\title{
An additional low layer transport of Sahelian and Saharan dust over the north-eastern Tropical Atlantic
} Isabelle Chiapello, G. Bergametti, Laurent Gomes, Bernadette Chatenet, François Dulac, José Pimenta, Emmanuel Santos Soares

\section{- To cite this version:}

Isabelle Chiapello, G. Bergametti, Laurent Gomes, Bernadette Chatenet, François Dulac, et al.. An additional low layer transport of Sahelian and Saharan dust over the north-eastern Tropical Atlantic. Geophysical Research Letters, 1995. hal-02326371

\section{HAL Id: hal-02326371 \\ https://hal.science/hal-02326371}

Submitted on 22 Oct 2019

HAL is a multi-disciplinary open access archive for the deposit and dissemination of scientific research documents, whether they are published or not. The documents may come from teaching and research institutions in France or abroad, or from public or private research centers.
L'archive ouverte pluridisciplinaire HAL, est destinée au dépôt et à la diffusion de documents scientifiques de niveau recherche, publiés ou non, émanant des établissements d'enseignement et de recherche français ou étrangers, des laboratoires publics ou privés. 


\title{
An additional low layer transport of Sahelian and Saharan dust over the North-Eastern Tropical Atlantic
}

\author{
I. Chiapello, G. Bergametti, L. Gomes, B. Chatenet, \\ Laboratoire Interuniversitaire des Systèmes Atmosphériques, Universités P7-P12, UA CNRS 1404, Créteil, France. \\ F. Dulac \\ Centre des Faibles Radioactivités, CEAVCNRS, Gif sur Yvette Cedex, France.
}

\author{
J. Pimenta and E. Santos Suares. \\ Serviço Nacional de Meteorologia i Geofisica, Sal, Cabo Verde.
}

\begin{abstract}
Mineral dust concentrations have been measured from a monitoring aerosol station set up at Sal, Cape Verde Island between December 1991 and December 1994 in order to assess the transport process of African dust over the North-eastern Tropical Atlantic. These measurements indicate a pronounced seasonal pattern, with maximum dust concentrations observed during winter. A meteorological analysis shows that the transport of dust occurs at low altitudes, in the trade winds layer, during this season. Large quantities of dust are carried out of Northwestern Africa, in particular from the Sahel at these altitudes. Such process could constitute the major supply of atmospheric mineral matter to the surface sea water of the Eastern Atlantic.
\end{abstract}

\section{Introduction}

Measurements show that in many oceanic regions the major aerosol constituent is mineral matter derived from continents. The greatest concentrations of soil aerosol particles are found over marine areas "downwind" of arid regions and deserts (D'Almeida, 1986). The Sahara desert is one of the major source areas for windblown dust in the Northern Hemisphere. It has been shown that large amounts of Saharan mineral dust experience long-range transport across the Northern Tropical Atlantic (Delany et al., 1967; Prospero and Nees, 1977; Schütz, 1980), providing material to the deep sea sediments (Sarnthein and Koopman, 1980) and soils of the Western Atlantic islands (Muhs et al., 1990), or nutrients to the Amazon forest (Swap et al., 1992) and sea surface-waters (Duce et al., 1991). Long-term aerosol studies have shown a seasonal pattern for the transatlantic transport of African dust, due to the seasonal shift of the InterTropical Convergence Zone (I.T.C.Z.); during summer, dust is transported above the trade winds atmospheric layer, in the socalled Saharan Air Layer (S.A.L.). This S.A.L. often reaches altitudes of 5-7 km, and extends as far as the Caribbean Sea and the south-eastern United States (Carlson and Prospero, 1972; Prospero and Carlson, 1972). During late winter and spring the dust transport shifts $10^{\circ}$ south, allowing dust particles to reach South America (Prospero et al., 1981). In contrast, very little is known on the transport pattern and seasonality in the oceanic

Copyright 1995 by the American Geophysical Union.

Paper number 95GL03313

0094-8534/95/95GL-03313\$03.00 regions off the African coast, mainly because collections over this region have been performed for short periods only either at islands sites (Jaenicke and Schütz, 1978; Bergametti et al., 1989; Prospero et al., 1977; Savoie and Prospero, 1977) or aboard ships (Chester and Johnson, 1971; Chester et al., 1971; Buat-Ménard and Chesselet, 1979). We report here three years of monthly averaged mineral dust concentrations from a monitoring aerosol station set up at Sal island, Cape Verde. The seasonality of dust transport is discussed with light of meteorological data and airmass trajectories. Results provide a new insight to source regions and transport pathways of mineral dust in the NorthEastern Tropical Atlantic.

\section{Data Set}

To assess the transport process of dust over the North-eastern Tropical Atlantic, we operate since December 1991 a daily aerosol sampling station at Sal, the most north-eastern island of the Cape Verde Archipelago $\left(16^{\circ} 45 \mathrm{~N}, 22^{\circ} 57 \mathrm{~W}\right)$, located $500 \mathrm{~km}$ west of the African coast. At the top of a $25-\mathrm{m}$ high tower located at an altitude of $100 \mathrm{~m}, 5 \mathrm{~km}$ from the eastern coastline, we collect daily filter samples $(0.4-\mu \mathrm{m}$-pore-size Nuclepore), with a flow rate of about $1 \mathrm{~m} 3 / \mathrm{h}$. Daily elemental silicon concentrations are determined by X-Ray fluorescence spectrometry, following to the method described by Losno et al. (1987). Subsequently, the total mineral dust concentration is estimated considering that silicon represents about $33 \%$ of the mineral aerosol (Bowen, 1966).

In order to interpret these measurements, we selected vertical profiles of wind direction (from the ground level up to altitude of ten kilometers) and other meteorological data from the operational meteorological radiosoundings of the atmosphere performed at Sal island by the S.N.M.G. (Serviço Nacional de Meteorologia i Geofisica).

Furthermore, air mass trajectories, associated to major dust events, have been computed from the three dimensional atmospheric transport model (TM2Z) (Ramonet et al., in press) in order to trace back the transport of aerosol particles from their source-regions.

\section{Results}

At Sal Island, the highest monthly averaged mineral aerosol concentrations occur in December or January. The summer concentrations are found to be at least 5 times lower (Fig. 1). This is consistent with climatological horizontal visibility recorded at 


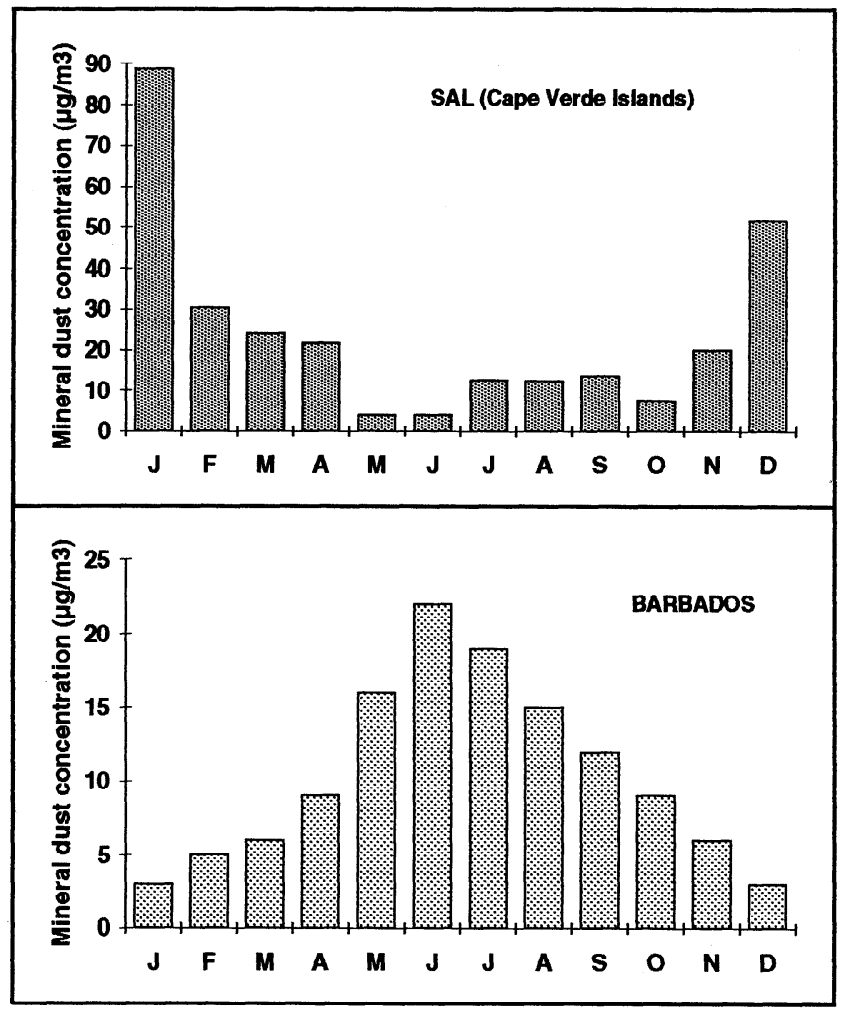

Figure 1. Monthly arithmetic mean of mineral dust concentrations at the surface level: (a) Sal, Cape Verde Island (19921994); (b) Barbados, Caribbean Sea (1973-1992).

Sal Island (Jaenicke and Schütz, 1978) which indicates that the highest visibilities ( 8 to $16 \mathrm{~km}$ ) are most frequent during the summer months, whereas visibilities of less than $8 \mathrm{~km}$ are observed mainly in winter. As shown in Fig.1, this seasonal cycle of dust concentration is opposite to that observed at Barbados, West Indies $\left(13^{\circ} 10 \mathrm{~N}, 59^{\circ} 30 \mathrm{~W}\right)$ where maximum concentrations occur in summer (June to August), the winter concentrations being 10-100 times lower (Prospero and Nees, 1977). The seasonal cycle observed at Sal also differs from that observed in Cayenne, French Guiana $\left(4^{\circ} 50 \mathrm{~N}, 52^{\circ} 22 \mathrm{~W}\right)$ where the maximum is observed in March (Prospero et al., 1981). The maximum monthly mean concentrations at $\mathrm{Sal}(120,95$ and $70 \mu \mathrm{g} / \mathrm{m} 3$ respectively for 1992, 1993 and 1994 respectively) are 3-5 times higher than recorded at Barbados (about $25 \mu \mathrm{g} / \mathrm{m} 3$ for the $1965-1992$ period) and Guiana (28 and $23 \mu \mathrm{g} / \mathrm{m} 3$, respectively for 1978 and 1979). Although these measurements were not taken over the same years, and interannual variability is to be expected, the higher concentration level observed at $\mathrm{Sal}$ than in western Atlantic stations is likely to be the result of the respective distances from the African coast (close to about $500 \mathrm{~km}$ for Cape Verde Islands as compared to several thousands for Barbados and Guiana).

\section{Discussion}

\section{Transport pattern}

As far as we know, the only descriptions of dust outbreaks over the Atlantic ocean are made for the summer meteorological situation. During this season, long-range dust transport occurs at high altitudes, within the so-called Saharan Air Layer (S.A.L.) above the trade winds inversion, located $1.5 \mathrm{~km}$ above sea level

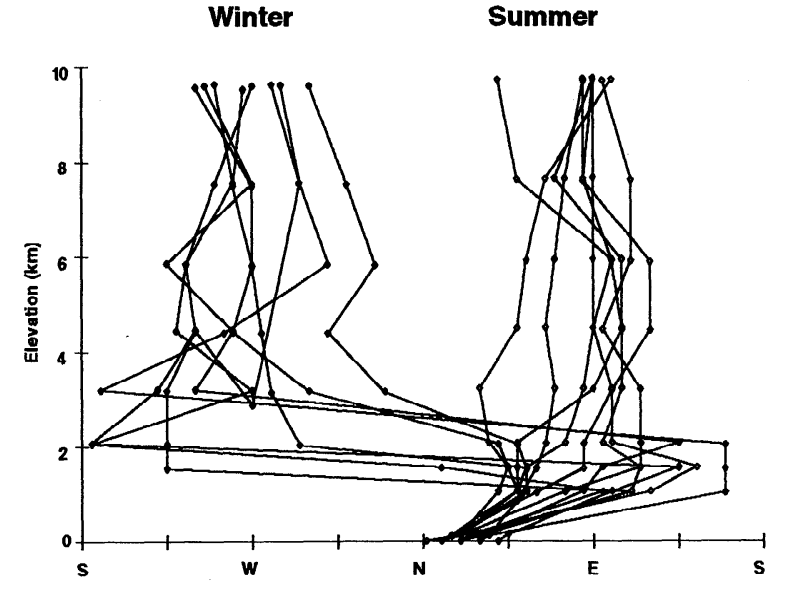

Figure 2. Typical winter (December 1991 and January 1992) and summer (July and August 1992) vertical wind direction profiles from radiosoundings performed at Sal (Cape Verde Islands).
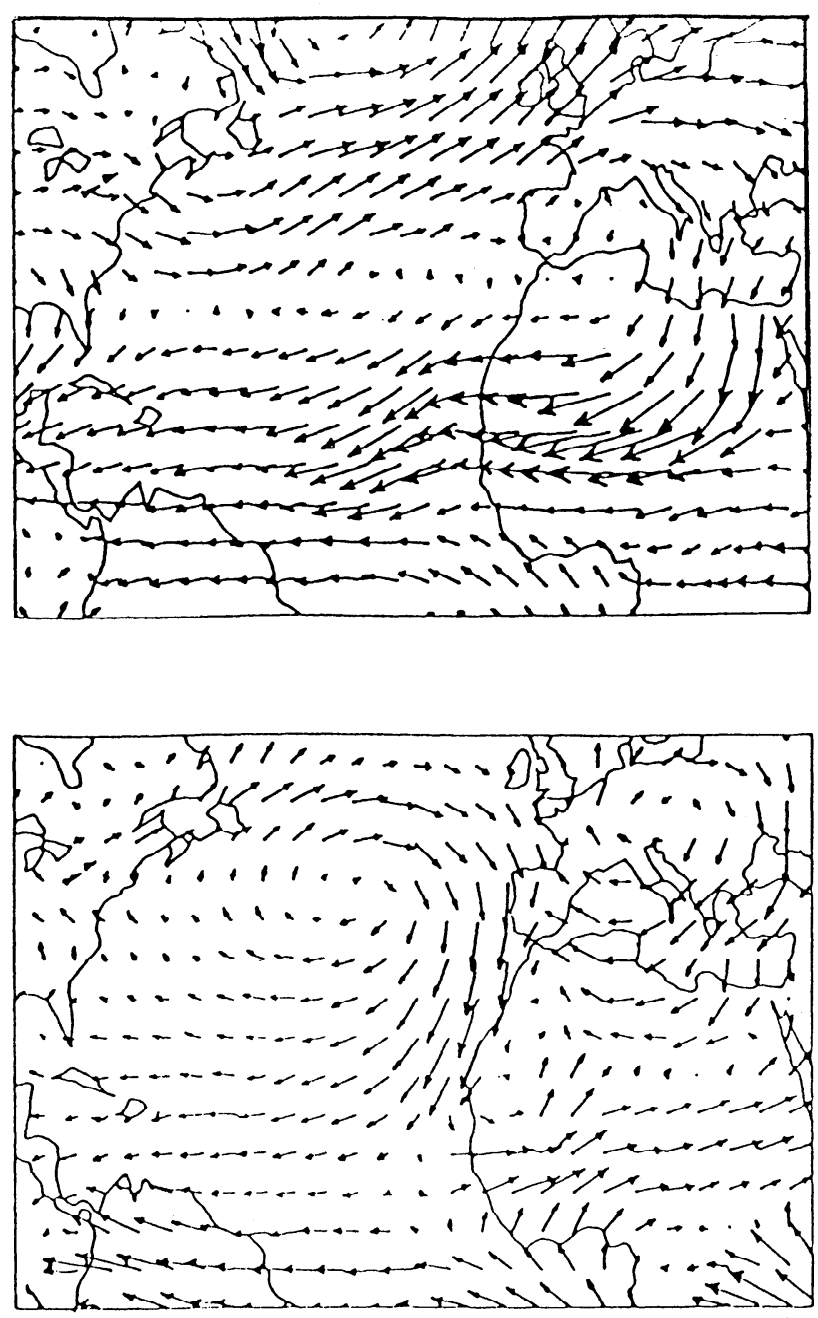

Figure 3. Average zonal wind fields in the layer $0-0.4 \mathrm{~km}$ over the Tropical North Atlantic for (a) January; (b) July (from M.S. Foreman-Fowler. GISS GCM diagnostics, monthly averages of winds for the 9 layers and geopotential heights at 700, 500, and 200 mb. Internal Report. Harvard University. April 1992.) 


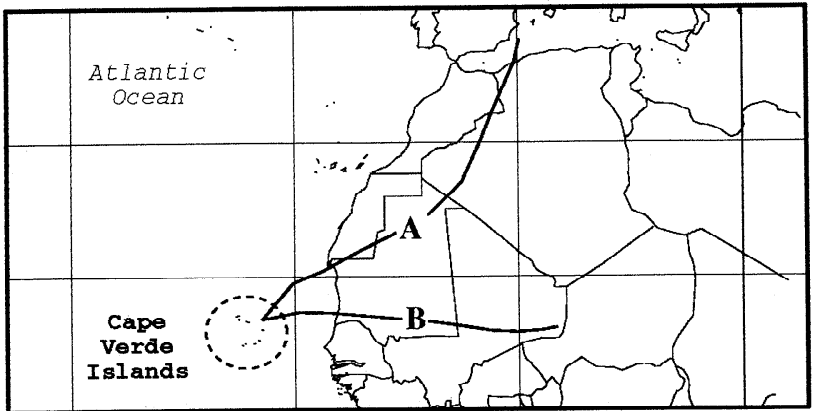

Figure 4. Air mass trajectories at 800 meter level corresponding to the two typical sources of dust events obscrved during winter in Cape Verde Islands. A: March 13, 1992; B: January 6, 1992.

(Prospero and Carlson, 1981). Indeed, considering the typical vertical profiles of wind direction in the Cape Verde Islands region (Fig. 2), easterly winds are dominant in summer throughout altitudes of up to $10 \mathrm{~km}$. During winter, easterly winds are restricted to a more shallow layer below, $1.5-3 \mathrm{~km}(850-700 \mathrm{mb})$, above, westerly "counter trade winds" prevail, setting the upper limit of the dust transport layer. This seasonal dependence is confirmed by the climatological vertical wind profiles established over the Atlantic (Schütz, 1980), and the African continent (Dubief, 1977).

Climatological zonal windfields in the north-eastern Tropical Atlantic are consistent with our observations of dust concentrations (Fig.3). Indeed, due to the seasonal meridional shift of the Azores anticyclone, the trade winds have an oceanic origin in summer, whereas in winter they move to a more continental origin. Consequently, during winter the region of Cape Verde Islands is localized across the main path of African dust transport in the north-east trade winds. Thus, the seasonal cycle of dust concentrations observed at ground level in Cape Verde Islands is dependent on a winter low layer transport in the trade winds. The low concentrations observed during summer at sea-level in Cape Vcrde are due to the fact that no mineral dust is carried by the trade winds at this time of the year. In fact, the African dust reaching Barbados during this season is transported over Cape Verde Islands, as shown by Meteosat images (Jankowiak and Tanré, 1992), but at high altitude and does not affect significantly the concentrations observed at Sal.

\section{Source Regions involved}

The backward trajectories, calculated for each dust event indicate two main origins for winter dust arriving at Cape Verde Islands (Fig.4). First, for a significant number of dust events, the trajectories indicate a northern origin, in western and central Sahara, involving similar source-regions than those previously shown to influence the summer transport (Mauritania, Northern Mali and Central Algeria) (Prospero and Carlson, 1981; Kalu, 1977; Bertrand et al, 1974). A second source region that is very active is located in the Sahelian zone, south of $20^{\circ} \mathrm{N}$. This is confirmed by reports of a major center of dust storm production in western Niger and northern Chad, with a maximum activity during the dry season between December and February (Kalu, 1977; Bertrand et al., 1974). Thus, it seems that some Saharan source-regions may be active for dust events observed in both winter and summer, but our results strongly suggest that additional southerly source-regions enhance significantly the dust concentrations observed in winter over the Eastern Atlantic.

\section{Conclusion}

Our observations indicate that a winter time dust transport in the trade winds layer takes place together with the well-known high altitude transport pattern to deliver Sahelian and Saharan dust to the North Tropical Atlantic. Because of the lower altitude of the dust transport, it is likely that this additional pathway affects only the Eastern North Tropical Atlantic. This supply of dust to the eastern northern Atlantic could dominate the annual budget to that region since we report both high concentrations in Cape Verde Islands in winter for such events and low surface concentrations in other scasons. This could have strong implications for both, the impact of atmospheric desert dust on the biological productivity of sea surface-waters and on the interpretation of deep sea sediment records.

Acknowledgments. The authors wish to thank Y. Balkanski for useful comments, P. Bousquet for the computation of trajectories and E. Bon Guyen for illustration. This work is supported by the «Programme Environnement du CNRS » in the framework of the action «Erosion Eolienne en Régions Arides et Semi-Arides ». This is CFR contribution $n^{\circ} 1738$.

\section{References}

Bergametti, G., L. Gomes, G. Coudé-Gaussen, P. Rognon and M.N. Le Coustumer, African dust observed over Canary Islands : source-regions identificationand transport pattern for some summer situations, J. Geophys. Res., 94, 14855-14864, 1989.

Bertrand, J., J. Baudet and A. Drochon, Importance des aérosols naturels en Afrique de louest, J. Rech. Atmosph., 8, 845-860, 1974.

Bowen, H. J. M., Trace elements in biochemistry, Academic Press, New-York, 1966.

Buat-Ménard, P. and R. Chesselet, Variable influence of the atmospheric flux on the trace metal chemistry of oceanic suspended matter, Earth and Planet. Sc. Lett., 42, 399-411, 1979.

Carlson, T. N. and J. M. Prospero, The large-scale movement of Saharan air outbreaks over the Northern Equatorial Atlantic, $J$. Appl. Meteorol., 11, 283-297, 1972.

Chester, R., H. Elderfield and J. J. Griffin, Dust transported in the North-East and South-East trade winds in the Atlantic Ocean, Nature, 233, 474-476, 1971.

Chester, R. and L.R. Johnson, Atmospheric dusts collected off the West African coast, Nature, 229, 105-107, 1971.

D'Almeida, G.A., A model for Saharan dust transport, J. Clim. Appl. Meteorol., 25, 903-916, 1986.

Delany, A.C., D.W. Parkin, J.J. Griffin, E.D. Goldberg and B.E.F. Reimann, Airborne dust collected at Barbados, Geochim. Cosmochim. Acta, 31, 885-909, 1967.

Dubief, J., Review of the North African climate with particular emphasis on the production of eolian dust in the Sahel zone and in the Sahara, in Saharan Dust: Mobilization, Transport, Deposition, edited by C. Morales, pp 27-48, Wiley, New-York, 1977.

Duce, R.A. et coll., The atmospheric input of trace species to the World Ocean, Global Biogeochim. Cycle, 5, 193-260, 1991.

Jaenicke, R. and L. Schütz, Comprehensive study of physical and chemical properties of the surface aerosols in the Cape Verde Islands region, J. Geophys. Res., 83, 3585-3599, 1978.

Jankowiak, I., and D. Tanré, Satellite climatology of Saharan dust outbreaks, J. of Climate, 5, 646-656, 1992.

Kalu, A.E., The African dust plume: its characteristics and propagation across West Africa in winter, in Saharan Dust: Mobilization, Transport, Deposition, edited by C. Morales, pp 95-118, Wiley, New-York, 1977.

Losno, R., G. Bergametti, and G. Mouvier, Determination of optima 
conditions for atmospheric aerosol analyses by X-ray fluorescence, Environ. Technol. Lett., 8, 77-87, 1987.

Muhs, D. R., C. A. Bush, K. C. Stewart T. R. Rowland and R.C. Crittenden, Geochemical evidence of Saharan dust parent material for soils developed on Quaternary limestones of Caribbean and Western Atlantic islands, Quaternary Res., 33, 157-177, 1990.

Prospero, J.M. and T.N. Carlson, Vertical and areal distribution of Saharan dust over the Western Equatorial North Atlantic Ocean, $J$. Geophys. Res., 77, 5255-2565, 1972.

Prospero, J.M. and T.N. Carlson, Saharan air outbreaks over the Tropical North Atlantic, Pageoph., 119, 677-691, 1980/81.

Prospero, J.M., R.A. Glaccum, and R.T. Nees, Atmospheric transport of soil dust from Africa to South America, Nature, 289, 570-572, 1981.

Prospero, J.M. and R.T. Nees, Dust concentration in the atmosphere of the Equatorial North Atlantic: possible relationship to the Sahelian drought, Science, 196, 1196-1198, 1977.

Prospero, J.M., D.L. Savoie, T.N. Carlson, and R.T. Nees, Monitoring Saharan aerosol transport by means of atmospheric turbidity measurements in Saharan Dust: Mobilization, Transport, Deposition, edited by C. Morales, pp 171-186, Wiley, New-York, 1977.

Ramonet, M., J.C. Le Roulley, P. Bousquet, and P. Monfray, Radon 222 measurements during the Tropoz 2 campaign and comparison with a global atmospheric transport model, J. Atmos. Chem., in press.
Sarnthein, M. and B. Koopman, Late Quaternary deep-sea record on Northwest African dust supply and wind circulation, Paleoecol. of Africa, 12, 239-253, 1980.

Savoie, D.L. and J.M. Prospero, Aerosol concentration statistics for the Northern Tropical Atlantic, J. Geophys. Res., 82, 5954-5963, 1977.

Schütz, L., Long range transport of desert dust with special emphasis on the Sahara, Ann. New-York Acad. Sci., 338, 515-532, 1980.

Swap, R., M. Garstang, S. Greco, R. Talbot and P. Kallberg, Saharan dust in the Amazon Basin, Tellus, 44B, 133-149, 1992.

I. Chiapello, G. Bergametti, L. Gomes and B. Chatenet, Laboratoire Interuniversitaire des Systèmes Atmosphériques, Universités P7-P12, UA CNRS 1404, 61 av. du Général de Gaulle, 94010 Créteil, France. (e-mail: bergametti@univ-paris12.fr)

F. Dulac, Centre des Faibles Radioactivités, CEA/CNRS, 91198 Gif sur Yvette Cedex, France.

(e-mail: dulac@asterix.saclay.cea.fr)

J. Pimenta and E. Santos Suares, Serviço Nacional de Meteorologia i Geofisica, Espargos, Sal, Cabo Verde.

(Received July 7, 1995; revised October, 10 1995;

accepted october, 22, 1995) 